Do afeto 


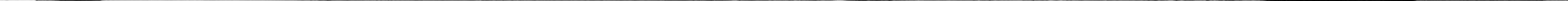




\title{
Um mestre inesquecível
}

\author{
Antonio Arnoni Prado*
}

No dia 16 de março de 1971, tive meu primeiro contato pessoal com o professor Antonio Candido, que eu tanto admirava através dos seus livros e dos textos que ele publicava em diferentes suplementos literários. Não preciso dizer que, desde os tempos do secundário, nunca deixei de alimentar a esperança de um dia poder vir a conhecê-lo e participar de suas aulas na antiga Faculdade da rua Maria Antônia.

Quis a vida que, três anos depois, já cursando Letras naquela faculdade, não pude conter a satisfação de vê-lo um dia passar discretamente pelos corredores, com uma pasta marrom debaixo do braço, a caminho da classe. Claro que essa reverência sempre me encheu de respeito e medo, mas sem nunca apagar o sonho de que eu viesse a figurar um dia entre os seus orientandos.

$E$ a vida ... bem a vida nos cobre surpresas que muitas vezes mal podemos entender. $\mathrm{O}$ fato é que, concluída a graduação, por insistência de colegas e amigos, decidi arriscar e acabei concorrendo a uma vaga em seu último curso pós-graduado em Teoria Literária, para o qual fui de peito aberto e cheio de apreensões

Morando nos confins da zona norte, lá para os lados da Cantareira, lembro bem da manhã cinzenta em que saí apressado de casa para me submeter à entrevista. Depois de semanas repassando os livros de Antonio Candido, anotando conceitoschave, resumindo contextos históricos, apontamentos de aula, confesso que no fundo não alimentava grandes esperanças de conquistar alguma coisa. * Professor titular da Universidade Federal de Campinas (UNICAMP).
Doutor em Letras pela Universidade de São Paulo(USP). 
Recordo ainda agora que, a caminho da USP em direção aos galpões provisórios da Cidade Universitária - para onde fomos transferidos depois daquela batalha contra os estudantes do Mackenzie - eu ia hesitante e sem a menor pressa de chegar. A dez minutos da prova, lembro que ainda estava lá em cima, no começo da rua Pio XI, nas proximidades da Fapesp.

Um misto de indignação e alívio parecia juntar-se ao alvoroço do meu atraso. Enfim - pensava comigo - se chegasse fora de hora, eu pelo menos evitaria fazer feio diante de um mestre que tanto respeitava.

Foi assim pensando que, às nove horas e quatro minutos - lembro como se fosse agora - bati à porta da sala de exames. "O sr. infelizmente está atrasado. Acabei de chamar o próximo inscrito e ele já está a caminho", disse-me um Antonio Candido compenetrado e calmo. Desculpei-me sem jeito e já me preparava para deixar a sala quando ele, antes de fechar a porta, acrescentou: "agora, só depois das dezessete horas, para quando está marcada a última entrevista".

Saí dali meio constrangido, sem saber direito para onde ir.

Foi então que resolvi me trancar na biblioteca para rever o material consultado, reavaliar as dúvidas que me perseguiam, como a justificar para mim mesmo que a ideia de que fazer pósgraduação em Teoria Literária era um desafio sem precedentes.

Só ao meio-dia, quando saí para tomar um lanche e conversar com alguns colegas que disputavam uma vaga comigo, vi que a coisa era bem mais séria do que eu pensava. Afinal, eu estava ali diante de um pessoal graúdo, professores da USP, gente relacionada ao ensino e à pesquisa, candidatos que sabiam grego e latim, sem contar alguns mestres em língua moderna, que trocavam palpites sobre os poetas que pretendiam citar como 
exemplo na prova - autores como Eliot, Trackl, Baudelaire, Rimbaud...

Mesmo assim, decidi ganhar tempo e voltei cismado à biblioteca, onde passei a tarde trabalhando. Às dezessete e vinte já fazia algum tempo que eu esperava do lado de fora da sala de exames, quando a porta de repente se abriu e o professor Antonio Candido me pediu para entrar.

Sem qualquer referência ao atraso da manhã, examinou detalhadamente as notas do meu histórico escolar para depois iniciar a entrevista me submetendo a uma série de perguntas de cultura geral.

Solicitou-me, por exemplo, que falasse um pouco sobre meus autores preferidos, sobre a qualidade da música que eu ouvia, do teatro que lia e dos compositores que eu admirava. Em seguida, pediu-me que explicasse em detalhes com que interesse eu decidi entrar para o curso de pós-graduação em Teoria Literária.

Não me lembro bem de como comecei a explicar nem do modo como respondi à pergunta. Disse apenas que sentia falta de um método que me ampliasse as perspectivas de conhecer melhor a estrutura dos livros que eu estudava. Foi ali que a coisa pegou fogo e a entrevista se transformou num verdadeiro cipoal: Antonio Candido quis discutir, por etapas, o caminho que eu costumava percorrer para chegar à análise das obras lidas.

Depois de argumentar por uns vinte minutos e de dizer tudo aquilo me vinha à cabeça, concluí esgotado e deixei a sala sem sequer imaginar qual seria a minha sorte depois de tanta elucidação misturada.

Dois dias depois, no entanto, ao conferir a relação dos aprovados no painel de avisos do departamento, nem acreditei quando vi que meu nome constava da lista. 
Tudo o que posso dizer é que os cinco anos seguintes me jogaram fundo num ciclo interminável de trabalhos, seminários e pesquisas que acabaram mudando radicalmente a minha vida. E hoje, quando penso que tudo passou e ficou tão distante, ainda me lembro de quando entreguei a Antonio Candido o meu texto de mestrado sobre a obra de Lima Barreto, que ele pôs em julgamento público na tarde de 5 de fevereiro de 1975, sob a arguição de Osman Lins e de Walnice Nogueira Galvão.

Aprovado pela banca, julguei que com o título de mestre as minhas obrigações terminavam por ali. Mas logo depois, pensando no que fazer para seguir o meu destino (especialização? doutorado? estágio no exterior?), eis que recebo um telefonema do Rio de Janeiro em que Francisco de Assis Barbosa, ele mesmo, o grande biógrafo de Lima Barreto, me chamava, convidandome para visitá-lo e levar comigo a tese que - ele explicava - "o Antonio Candido me disse que eu precisava ler e julgar para ver se merecia ser publicada".

Difícil dizer o que senti naquele momento. E ainda hoje me vejo andando ao lado de Assis Barbosa pelas ruas convulsas de um Rio de Janeiro cheio de buracos e escavações do metrô em construção, a caminho da editora Cátedra, que publicou o livro no ano de 1976 em colaboração com o Instituto Nacional do Livro.

Não tive coragem de pedir a Assis Barbosa que escrevesse um prefácio, porque na verdade sempre julguei que, prefácio por prefácio, era a voz de Antonio Candido que eu ouvia reboando no interior do livro, com a distância sempre comedida e o desejo de permanecer anônimo.

Dos Estados Unidos, onde então fazia um curso de especialização em romance moderno na Universidade de Indiana, sempre senti falta de aulas como as dele. 
A verdade é que lá não havia um Antonio Candido ou alguém que, como ele, ensinasse, discutisse e explicasse literariamente os meandros mais densos que organizavam um texto.

A tal ponto que Guimarães Rosa era tido ali como uma espécie de ilustração secundária e apagada entre os regionalistas da América Latina. E pior: era lido fora dos deslindes da linguagem mágica que emanava de seus livros, fazendo com que poucos se arriscassem a aproximar-se para tentar ao menos compreendê-los por dentro.

Voltei para S. Paulo e comecei o doutorado com Antonio Candido no segundo semestre de 1976. Além dos cursos e seminários, nasceu daí uma convivência que me motivou pela vida afora.

Ao longo do tempo, já livre dos seminários de trabalho, segui aprendendo com ele e conversando por horas inteiras na ampla sala de seu apartamento de S. Paulo, onde a literatura e a cultura como que se renovavam ante o manancial de lembranças de sua memória incomparável. Conversas com Mário, palpites de Oswald, lembranças de Guimarães Rosa, tudo vinha de repente à baila em meio a um coro de vozes discrepantes a que se misturavam as palavras serenas de Emílio Moura, a erudição de Sérgio Buarque de Holanda, a humildade de Manuel Bandeira, quase todos emparceirados ordenadamente nas estantes que circundavam em silêncio as nossas conversas animadas.

$\mathrm{Na}$ hora de ir embora, Antonio Candido me acompanhava gentilmente até a porta do elevador, antes que nos despedíssemos. Naquela tarde, a última em que o visitei, não sei por que enlacei o braço esquerdo em torno de seus ombros como jamais fizera antes. 
Já no elevador, descendo, fui lamentando intimamente aquele gesto desarvorado. Só depois me realimentei de conforto quando reconheci que fora justamente aquele o nosso derradeiro adeus. 